\title{
Network Externalities in Telecommunication Industry: An Analysis of Serbian Market ${ }^{3}$
}

\author{
Article history: \\ Received:23 August 2015 \\ Sent for revision:16 September 2015 \\ Received in revised form:5 January 2016 \\ Accepted: 13 January 2016 \\ Available online: 1 April 2016
}

\begin{abstract}
This paper deals with network competition and provides empirical analysis of market concentration, network and call externalities, access pricing, price discrimination and switching costs in Serbian mobile phone telecommunications market. It is shown that network externalities governed the expansion of this market until 2008. Upon entry of VIP incumbents didn't engage in predatory behaviour towards entrant aiming to benefit from lockedin users. The policy of mobile phone number portability reduced on-net prices and substantially increased consumer's surplus. In contrast to some previous research, this policy was pro-competitive in Serbia. We have also determined that users of the network with the largest market share benefit the most from call externalities. Finally, one network does not price discriminate between outgoing and incoming roaming calls, which implies that users of this network have higher level pecuniary externalities in roaming compared to users of price discriminating networks.
\end{abstract}

Keywords: Telecommunication industry, network externalities, call externalities, switching costs, price discrimination.

\section{Mrežne eksternalije u telekomunikacionoj industriji: analiza srpskog tržišta}

Apstrakt: Rad se bavi mrežnom konkurencijom i empirijski analizira tržišnu koncentraciju, mrežne i eksternalije dolaznih poziva, interkonekciju, diskriminaciju cena i troškove prelaska na srpskom tržištu telekomunikacija.

\footnotetext{
${ }^{1}$ University of Belgrade, Faculty of Economics, dejan@ekof.bg.ac.rs

${ }^{2}$ University of Belgrade, Faculty of Economics, dorde@ekof.bg.ac.rs

${ }^{3}$ This paper was presented at the conference organized by International Institute of Social and Economic Sciences in London (2015).
} 
Trifunović D., Mitrović Đ.: Network Externalities in Telecommunication Industry: An...

Mrežne eksternalije su uzrokovale ekspanziju ovog tržišta sve do 2008. godine. Nakon ulaska VIP-a na tržište, postojeći operateri se nisu ponašali predatorski prema VIP-u i nastojali su da profitiraju od potrošača koji su imali visoke troškove prelaska. Omogućavanje prenosa brojeva između operatera je dovelo do smanjenja cene poziva u mreži $i$ značajnog povećanja potrošačkog viška. Nasuprot nekim prethodnim istraživanjima, ova politika je povećala nivo konkurencije na tržištu. Utvrdili smo da su korisnici kompanije sa najvećim tržišnim učešćem imali najveće koristi od pozitivnih eksternalija dolaznih poziva. Najzad, jedan operater ne primenjuje cenovnu diskriminaciju odlaznih i dolaznih poziva u romingu što ima za posledicu da njegovi korisnici imaju veći nivo negativnih eksternalija dolaznih poziva u romingu od korisnika mreža koje vrše cenovnu diskriminaciju.

Ključne reči: telekomunikacije, mrežne eksternalije, pozitivne eksternalije dolaznih poziva, troškovi prelaska, cenovna diskriminacija.

\section{Introduction}

This paper deals with network externalities in telecommunication industry when the utility of one user increases with the number of users using the same service. ${ }^{4}$ The literature in this field originates from Rohlfs (1974) who studied pricing decision of monopoly with network externalities. ${ }^{5}$ Many papers followed this pioneering work, but the most influential impact in the field was made by the Nobel Prize winner Jean Tirole and his late co-author Jean Jacques Laffont. They wrote a series of papers on network externalities.

In the first paper, Laffont and Tirole (1994) study access pricing when one telecommunication company where a call originates has to pay to its competitor for the service of terminating a call on its network. In the following paper, Laffont, Rey and Tirole (1998a), network competition in an oligopolistic industry is formalized in Hoteling's model of spatial competition where consumers are uniformly distributed along the unit interval according to their preferences to networks. Two competing networks are located at the opposite ends of unit interval and user's utility contains disutility term that captures the loss in utility from subscribing to network that is not his ideal choice. This paper studies competition in linear per minute prices when networks do not

\footnotetext{
${ }^{4}$ Recall from basic microeconomics that externalities exist when utility of one agent is affected by actions of another agent.

${ }^{5}$ An effort to understand empirically the scale of network externalities was provided by Doganoglu and Grzybowski (2007) who figured out that prices of per minute calls in Germany should have become negative to explain huge increase in the number of users in the absence of network externalities. For a short survey of main theoretical models in this field see Peitz, Valletti and Wright (2004).
} 
Trifunović D., Mitrović Đ.: Network Externalities in Telecommunication Industry: An...

discriminate between on-net and off-net calls. Access charges could be regulatory or market determined and in the latter case, the equilibrium per minute price is characterized by double mark-up (it is higher than monopoly price). They also study two-part tariffs when users pay per minute price and fixed subscription fee. Their companion paper, Laffont, Rey and Tirole (1998b), studies price discrimination in the same setup, when operators price discriminate between outgoing on-net and off-net calls. Operator's market share depends on indirect utility that it provides to users and this in turn depends on on-net off-net price differential. Equilibrium off-net price is higher than on-net price due to access pricing costs but also due to mark-up over access costs that operator imposes. Empirical research of Birke and Swann (2006) determines that the difference in volume between on-net and off-net calls is not only the consequence of price discrimination and that the difference exists, although at a smaller scale, even without price discrimination and might be explained by coordinated choice of operator among friends and family. The following paper by Jeon, Laffont and Tirole (2004) analyses receiver pays principle, when receiver also pays for receiving incoming calls. ${ }^{6}$ When user of one network makes outgoing calls, user of other network benefits from call externalities by receiving free calls. In the US, user pays for receiving calls and this might be a consequence of incompatible standards that are used it this market. In contrast, in Europe operators use standardized technology ${ }^{7}$ and receiver pays only for roaming service. In this case, length of a call is mutually determined by both caller and receiver who is sovereign to hang up. In other words, the length of a call is determined as the minimum between caller's demand for outgoing calls and receiver's demand for incoming calls. When the volume of calls from one network to other increases, receiver who is supposed to pay for receiving calls, experiences direct call externalities due to the fact that he receives more calls and at the same time he is also subject to pecuniary externalities that stem from higher payments for receiving calls. ${ }^{8}$

One more interesting aspect from industrial organization point of view concerns entry in the market. The paper of Peitz (2005) deals with

\footnotetext{
${ }^{6}$ When user's valuation of outgoing and incoming calls are his two-dimensional private information and when these valuations are positively correlated, Hahn (2003) derives an interesting result where the usual condition for asymmetric information environment, "no distortion on the top", does not hold since even the user with the highest valuation makes inefficiently low volume of outgoing calls.

${ }^{7}$ Koski and Kretsmacher (2005) determine that price competition is more intensive with incompatible technology.

${ }^{8}$ All the previously analyzed models are based on the random calling pattern assumption. However, there might be some users that make more outgoing calls than others. This issue was discussed by Dessein (2004) who distinguish between heavy (business) and light (private) users.
} 
Trifunović D., Mitrović Đ.: Network Externalities in Telecommunication Industry: An...

asymmetric access price regulation when incumbent is supposed to set access charge to cost of providing this service and entrant is allowed to use a mark-up over costs. This policy, that is intended to be temporary in nature until entrant catches up incumbent, should facilitate entry and increase entrant's profit. Consumer's surplus is increased as well at the cost of slight reduction of welfare that stems from inefficient pricing by incumbent. Regarding entry strategies, de Bijl and Peitz (2004) consider 3 types of entry: facility based entry when entrant builds its own network, local loop unbundling when entrant leases incumbent's network and carrier select when entrant pays access charge not only for incoming calls from incumbent's network, but also for outgoing calls regardless of the destination network as a compensation for using incumbent's network. In dynamic context, regulatory policy should promote the second two types of entry in the short run since they are less expensive and the first type of entry in the long run.

The issue of price discrimination between on-net and off-net calls could be analyzed in the context of entry deterring and predatory behaviour. This is the line of reasoning of Calzada and Valletti (2008) who assume that incumbents faced with entry in the market strategically increase price discrimination above Nash equilibrium level to deter entry. This behaviour sacrifices part of their profit, but it pays off if entry is blocked. On the other hand, Hoering (2007) claims that higher off-net prices set by incumbent than by entrant need not reflect predatory behaviour. If more calls are directed from incumbent's network towards entrant's network than in the reverse direction (which is natural assumption since incumbent is larger), users of entrant's network benefit more from call externalities and incumbent sets higher off-net price to internalize these externalities.

Previous models were based on Hoteling's spatial competition. The other approach is to assume that users have switching costs of changing operator. One of the reasons for the existence of switching costs, mentioned by Gabrielsen and Vagstad (2008) that lock-in user with one operator, is the fact that members of friends and family group belong to the same network. Thus, by changing operator, switching user would have to pay higher off-net prices for calling members of his circle and price discrimination creates switching costs. The largest switching cost for user is related to change of mobile phone number when changing network. This is the main reason for lock-in. Grzybowski and Pereira (2011) determine that switching costs in Portugese market are quite large. For that reason, regulators have adopted the policy of mobile phone number portability to reduce the switching cost when user can retain his current number when changing network. A research approach of Shi, Chiang and Rhee (2006) provided some puzzling conclusions concerning this policy based on evidence from Hong Kong market where companies had asymmetric market shares. In this market, the policy has made some anticompetitive effects and increased the market share and profit of large 
Trifunović D., Mitrović Đ.: Network Externalities in Telecommunication Industry: An...

operators at the expense of smaller operators. They have built a model based on the switching cost tradition to explain this paradox. The main conclusion is that large networks charge higher subscription fee to extract consumer's surplus due to lock-in. At the same time, users of large network benefit from making larger share of cheaper on-net calls than users of small network. If this positive on-net discount effect dominates the negative lock-in effect, large network increases its market share upon the adoption of mobile phone number portability policy. Grzybowski and Liang (2015) consider switching costs when consumers buy bundles consisting of fixed and mobile phone services as well as ADSL and IPTV and find that switching costs include uncertainty whether a new bundle will be tailored according to their needs.

Based on the previous theoretical results, this paper aims to verify or reject these conclusions on data from Serbian market. The first hypothesis that is checked is that the expansion of the market was governed more by network externalities than by price reductions. The second hypothesis is that the policy of mobile phone number portability was pro-competitive and welfare improving in Serbia in contrast to previous research. The third objective of this paper is to determine the level of call externalities and how they affect pricing strategies. The fourth hypothesis is to prove that price discrimination increased trough time mainly due to reduction of on-net prices. The last objective is to verify if the trend of roaming prices could be identified. The underlying assumptions of the analysis is that market has strong network effects and that operators use profit maximizing strategies that consist of choosing different degrees of price discrimination as well as product differentiation.

\section{Research methodology and data}

The research methodology is based on the concepts from industrial organization such as market concentration, network externalities, call externalities, access pricing, price discrimination, spatial competition and switching costs. First, in order to determine market concentration, $\mathrm{HHI}$ is calculated as $H H I=\sum_{i=1}^{n} s_{i}^{2}$, where $s_{i}$ is a market share of company $i$. Second, Gomeprtz's growth curve is estimated to determine market saturation as well as the effect of network externalities. Third, the share of pre-paid users is used as an approximation of the level of call externalities. Fourth, switching costs are measured as the share of users that change operator. Fifth, calculation of interconnection costs is based on OECD methodology that proposes a division of outgoing calls depending on their destination: fixed, mobile network or voice mail. Sixth, the degree of price discrimination is calculated as the ratio of on-net to off-net price. Finally, the level of pecuniary externalities is measured by the price of incoming roaming call. 
Trifunović D., Mitrović Đ.: Network Externalities in Telecommunication Industry: An...

The data sample is based on available data from RATEL's ${ }^{9}$ site and from official internet sites of operators in Serbian market. The data presented in official annual financial and business reports of Telenor Group, ${ }^{10}$ Telekom Austria Group ${ }^{11}$ and Telekom Serbia Group ${ }^{12}$ were also used. Unfortunately, it was not possible to obtain data about costs and selling prices of mobile services directly from operators and price calculations were based on information about basic post-paid packages available on current and historical internet sites of mobile services providers (data about subscription fees and total number of available minutes for off and on-net calls). We further explain in detail below in the text sources of data and how data were constructed in some of our analyses. Time series of available data are not long enough to permit statistical inference (data are mostly from period 2007-2014). Nevertheless, this research provides numerous interesting insights and on some occasions quite different conclusions from those suggested by theoretical models were obtained.

\section{Empirical results and discussion}

In this part the description of the market and its concentration is presented, network and call externalities are analysed as well as reduction of switching costs, price discrimination, access revenue and receiver pays principle.

\subsection{Description of the oligopolistic market}

In the domain of public mobile telecommunications networks in Serbia RATEL is in charge of issuing licences to potential mobile operators. These operators obtained ten years licences for Serbian territory. After expiration, licences may be extended for additional ten years without a special request from the mobile operator. The main condition is that operator fulfils the licence requirements. According to RATEL annual reports, in 2015, there are three providers in Serbian mobile telecommunications market. ${ }^{13}$

Telecommunications Company Telekom Srbija - MTS (licence replaced, valid as of August $\left.15^{\text {th }}, 2006\right)$ started working in August 1998. The company was

\footnotetext{
${ }^{9}$ Serbian Telecommunication Agency

${ }_{11}^{10} \mathrm{http}: / /$ www.telenor.com/investors/reports/

${ }^{11} \mathrm{http}: / /$ www.telekomaustria.com/en/ir/results-center

${ }^{12} \mathrm{http}: / /$ www.telekom.rs/telekomeng/Contents/ContentDefault.aspx?temp=0\&sid=1291 \&id $=1298$

${ }^{13}$ RATEL. 2015. An Overview of the Telecom and Postal Services Market in the Republic of Serbia in 2014. http://www.ratel.rs/upload/documents/Pregled_trzista/ratepregled-trzista-za-2014-ENGLESKI-web.pdf
} 
Trifunović D., Mitrović Đ.: Network Externalities in Telecommunication Industry: An...

founded in June 1997 as a shareholders' company with the majority ownership by the Republic of Serbia at $51 \%$, then rising to $80 \%$ in 2003 , with the remaining $20 \%$ owned by the Greek OTE operator. Currently, $58.11 \%$ is owned by Serbian Government, $20 \%$ is owned by Telekom Srbija, $14.95 \%$ is owned by Serbian citizens and the remaining $6.94 \%$ is owned by current and former employees. In addition to Serbian market, Telekom Srbija is also present as operator through daughter companies in Republic of Srpska and Montenegro. The company reached 4,062 base stations by the end of 2014 .

Telenor Ltd., Belgrade, 100\% owned by Telenor A/S, Denmark (licence issued on August $31^{\text {st }}, 2006$ ) is second provider. The Norwegian company Telenor has been present in Serbian telecom market since 31 July 2006, when they bought Mobtel (the first mobile telephony operator in Serbia) in a Dutch-Anglo auction ${ }^{14}$. Telenor Ltd. is a part of Telenor Group, operating in 13 countries across Europe and Asia and another 17 countries through ownership in VimpelCom. The mobile operators from Telenor Group in the neighbouring countries are Telenor Hungary, Telenor Montenegro and Telenor Bulgaria. In 2014 Telenor's network consisted of 3,398 base stations.

The third provider is VIP mobile Ltd., $100 \%$ in the ownership of Mobilkom CEE, Austria (licence issued on December $1^{\text {st }}, 2006$ ). This operator is a member of the Telekom Austria Group, operating in eight European countries, including other countries in the region like Montenegro, Croatia, Bulgaria and Macedonia. In addition to 320 million and 1 euros paid for the licence, Mobilkom Austria made considerable investments in the network roll out and development. In 2014, VIP's network used 2,966 base stations. Table 1 presents the main official data regarding three mobile providers in Serbia.

Table 1. Serbian mobile telephony network - service coverage per operators

\begin{tabular}{|l|r|r|r|}
\hline \multirow{2}{*}{\multicolumn{1}{|c|}{ Main indicators (2014) }} & \multicolumn{3}{c|}{ Mobile telephony operators } \\
\cline { 2 - 4 } & \multicolumn{1}{|c|}{ Telenor } & \multicolumn{1}{c|}{ MTS } & \multicolumn{1}{c|}{ VIP } \\
\hline Territory covered by GSM network signal & $91.75 \%$ & $89.75 \%$ & $84.50 \%$ \\
\hline Population covered by GSM network & $99.38 \%$ & $99.75 \%$ & $98.60 \%$ \\
\hline Territory covered by UMTS & $69.77 \%$ & $85.41 \%$ & $45.00 \%$ \\
\hline Population covered by UMTS network & $83.68 \%$ & $97.16 \%$ & $82.50 \%$ \\
\hline Base stations (number) & 3,398 & 4,062 & 2,966 \\
\hline
\end{tabular}

Source: RATEL. 2015. An Overview of the Telecom and Postal Services Market in the Republic of Serbia in 2014.

\footnotetext{
${ }^{14}$ This is a hybrid auction where in the first stage bidders submit bids in sealed envelopes in a first-price auction and in the second stage two bidders with the highest first stage bids compete in English auction. More detailed analysis of auctions with interdependent values and hybrid auctions could be found in Trifunović (2011) and Trifunović and Ristić (2013).
} 
Trifunović D., Mitrović Đ.: Network Externalities in Telecommunication Industry: An...

In 2006 the third license was issued to VIP. Recall that de Bijl and Peitz (2004) distinguish 3 types of entry: facility-based entry, local loop unbundling and carrier select. In the first years of operation VIP used carrier select type of entry paying to MTS for using its network for outgoing calls. Dynamically, the regulator should induce entrant to invest in its own network. Indeed, VIP had strong investment activity to build its network. ${ }^{15}$ Nevertheless, in some rural and sparsely populated areas, VIP still relies on competitors' networks.

Table 2. Carrier select payment of VIP (2007-2014)

\begin{tabular}{|l|r|r|r|r|r|r|r|r|}
\hline & $\mathbf{2 0 0 7}$ & $\mathbf{2 0 0 8}$ & $\mathbf{2 0 0 9}$ & $\mathbf{2 0 1 0}$ & $\mathbf{2 0 1 1}$ & $\mathbf{2 0 1 2}$ & $\mathbf{2 0 1 3}$ & $\mathbf{2 0 1 4}$ \\
\hline Total costs of national roaming (million EUR) \\
\begin{tabular}{|l|r|r|r|r|r|r|r|r|}
\hline MTS & 8,301 & 20,643 & 22,594 & 2,320 & 279 & 0 & 0 & 0 \\
\hline Telenor & 0 & 0 & 0 & 4,266 & 3,579 & 2,174 & 1,716 & n/a \\
\hline Average costs of nation roaming per user (EUR) \\
\hline MTS & 16.37 & 23.50 & 19.65 & 1.71 & 0.17 & 0.00 & 0.00 & 0.00 \\
\hline Telenor & 0.00 & 0.00 & 0.00 & 3.14 & 2.18 & 1.07 & 0.78 & n/a \\
\hline
\end{tabular}
\end{tabular}

Source: Authors' calculation based on mobile operators' audited annual financial statements

It is evident that upon the entry VIP used MTS's network trough carrier select type of entry and paid to MTS 23.5 EUR/user in 2008 and 19.65 EUR/user in 2009 for using its network for outgoing calls. In 2010 this amount was considerably reduced when VIP started using more intensively its own network. From that year, VIP used Telenor's network for reaching users in sparsely populated areas and the amount paid for this service declines as the coverage of VIP's network expands.

\subsection{Network externalities effects and market concentration}

Concerning the number of subscribers in Serbia, Table 3 provides data about total number of users and about number of users of each network. The market has experienced rapid growth, particularly in the period 2003-2008. In this period consumers' utility was substantially increased due to the network externalities effect when utility of one user increases with total number of users. This result is similar to Grajek (2010) who find that network effects increased the size of Polish market 10 times in the period 1996-2001. It seems that the market almost achieved the theoretical full coverage in the next year and the entrant obtained new subscribers mainly at the expense of incumbents.

\footnotetext{
${ }^{15}$ Capital expenditures of VIP in the period 2010-2014 in millions EUR - 2010: 47.5; 2011: 55.9; 2012 - 57.0; 2013 - 52.7; 2014: 37.8.
} 
Trifunović D., Mitrović Đ.: Network Externalities in Telecommunication Industry: An...

Table 3. Number of users of mobile network in Serbia (2003-2014)

\begin{tabular}{|l|r|r|r|r|r|r|r|r|}
\hline \multirow{2}{*}{ Year } & \multicolumn{4}{|c|}{ Number of users (000) } & \multicolumn{5}{c|}{ Growth rate (\%) } \\
\cline { 2 - 9 } & \multicolumn{1}{|c|}{ Total } & \multicolumn{1}{c|}{ MTS } & \multicolumn{1}{c|}{ Telenor } & \multicolumn{1}{c|}{ VIP } & \multicolumn{1}{c|}{ Total } & \multicolumn{1}{c|}{ MTS } & Telenor & \multicolumn{1}{c|}{ VIP } \\
\hline 2003 & 3,280 & 1,807 & 1,473 & 0 & & & & \\
\hline 2004 & 4,340 & 2,322 & 2,018 & 0 & 32.32 & 28.47 & 37.03 & \\
\hline 2005 & 5,510 & 2,992 & 2,518 & 0 & 26.96 & 28.86 & 24.77 & \\
\hline 2006 & 6,640 & 4,176 & 2,463 & 0 & 20.51 & 39.59 & -2.17 & \\
\hline 2007 & 8,450 & 5,019 & 2,924 & 507 & 27.26 & 20.18 & 18.68 & \\
\hline 2008 & 9,620 & 5,669 & 3,073 & 878 & 13.85 & 12.95 & 5.09 & 73.24 \\
\hline 2009 & 9,910 & 5,916 & 2,844 & 1,140 & 3.01 & 4.36 & -7.44 & 30.88 \\
\hline 2010 & 9,920 & 5,555 & 3,006 & 1,359 & 0.10 & -6.10 & 5.68 & 18.22 \\
\hline 2011 & 10,180 & 5,406 & 3,135 & 1,642 & 2.62 & -2.69 & 4.31 & 20.82 \\
\hline 2012 & 10,040 & 4,598 & 3,404 & 2,038 & -1.38 & -14.93 & 8.55 & 24.12 \\
\hline 2013 & 10,110 & 4,529 & 3,367 & 2,214 & 0.70 & -1.50 & -1.09 & 8.63 \\
\hline 2014 & 10,152 & 4,524 & 3,377 & 2,251 & 0.42 & -0.12 & 0.32 & 1.65 \\
\hline
\end{tabular}

Source: RATEL. 2015. An Overview of the Telecom and Postal Services Market in the Republic of Serbia in 2014 and authors' calculation

In the terminology of Rohlfs (1974) the market reached the stable equilibrium. We don't have relevant data before 2003, but we speculate that the critical mass of users when users' expectations are self-fulfilling and the growth rate of new users is self-sustained was reached prior to 2003. From 2009 the growth rate of overall subscribed population was tiny and the market has witnessed even negative growth rate in 2011. Moreover, the cumulative growth rate of the total number of subscribers from $2011-2014$ was $-0.27 \%$.

The conclusion that the market has reached saturation (stable equilibrium) is strengthened with the following graph where Gompertz's growth curve is estimated on quarterly data from 2006. According to the projection, the market will remain at the level of around 10 million subscribers in future. Some earlier estimates from 2009 have overestimated the potential of Serbian market claiming that the stable equilibrium will be achieved with 12 million subscribers. ${ }^{16}$

Table 3 also provides an insight how the market shares of 3 companies evolved. When VIP entered the market it had high growth rate of the number of users. But this effect was due to the low initial level of subscribers. When the market reached the full coverage, the entrant expanded its market share by attracting users from incumbents.

${ }^{16}$ Business Monitor International, Serbia Telecommunications Report 2009, March 2009. 
Trifunović D., Mitrović Đ.: Network Externalities in Telecommunication Industry: An...

Figure 1. Mobile network users in Serbia - projection

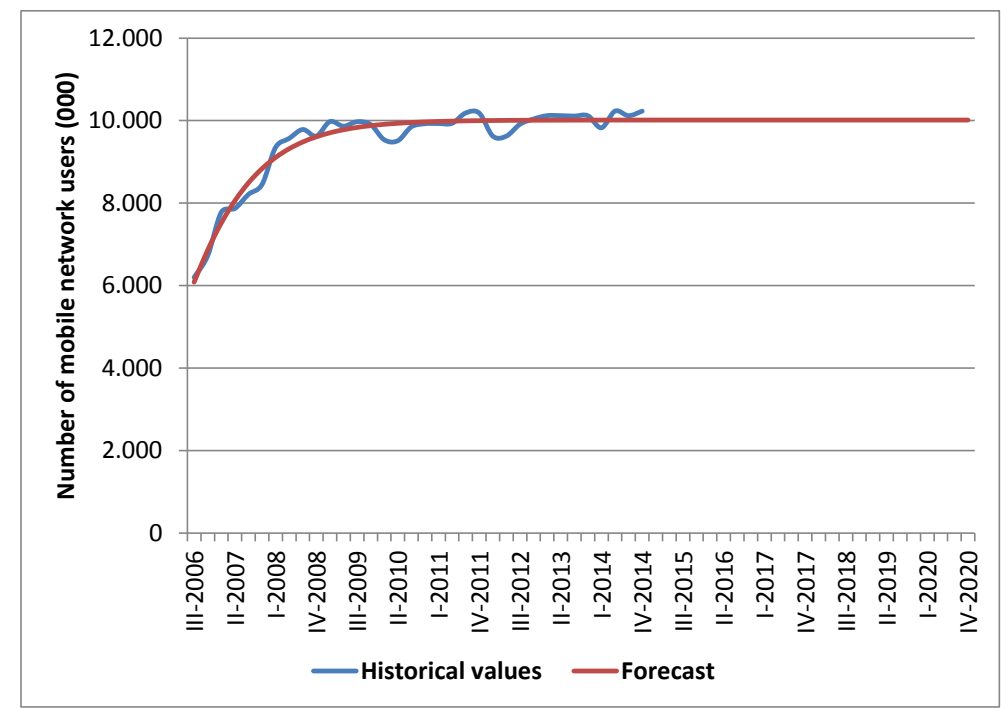

Source: Authors' calculation

It seems that the market position of state-owned MTS is particularly vulnerable since it has recorded negative growth rate in the number of subscribers in 5 consecutive years, although the company managed to stabilize its market share in the last years. The cumulative growth rate of MTS in the period 20092014 was $-23.54 \%$ and it has lost almost 1.4 million users. This fact might be a strong argument that the state-owned company is inefficient. In the same period, two other competitors had positive cumulative growth rate: Telenor $(+18.75 \%)$ and VIP (+95.79\%). It is also evident that in the last year even the fastest growing company, VIP, had the lowest growth rate in its history.

We will now analyse how the average price for outgoing calls of operators evolved in time. ${ }^{17}$ Prices reduced as expected, which is in line with the Rohlfs (1974) theory that prices should decrease to induce more consumers to subscribe. Table 4 shows that prices were significantly reduced from 2003 until 2008 (the last year of substantial market growth). However, the increase in the number of subscribers in this period was mainly based on network externality effect. Further analysis provides evidence for this claim.

\footnotetext{
${ }^{17}$ Average prices for outgoing calls (EUR/min) are calculated as average of official tariffs per minute for off-net and on-net outgoing calls in case when post-paid subscriber spends minutes out of package (i.e. tariffs per minute for outgoing calls for minutes not initially included in post-paid package and not covered by subscription fee).
} 
Trifunović D., Mitrović Đ.: Network Externalities in Telecommunication Industry: An...

Table 4. Average price for outgoing calls (EUR/min, 2003-2014)

\begin{tabular}{|c|c|c|c|}
\hline Year & MTS & Telenor & VIP \\
\hline 2003 & 0.52 & 0.36 & \\
\hline 2004 & 0.37 & 0.31 & \\
\hline 2005 & 0.26 & 0.32 & \\
\hline 2006 & 0.24 & 0.36 & \\
\hline 2007 & 0.27 & 0.31 & \\
\hline 2008 & 0.16 & 0.27 & 0.19 \\
\hline 2009 & 0.12 & 0.15 & 0.10 \\
\hline 2010 & 0.11 & 0.12 & 0.10 \\
\hline 2011 & 0.10 & 0.12 & 0.11 \\
\hline 2012 & 0.09 & 0.10 & 0.09 \\
\hline 2013 & 0.08 & 0.10 & 0.07 \\
\hline 2014 & 0.07 & 0.08 & 0.07 \\
\hline
\end{tabular}

Source: Authors' calculation

From 2009 until 2014, prices declined but the number of users changed very slightly. Thus, the effect of network externalities was exploited before 2008 and even substantial price cuts cannot increase the subscribers' base. Price reduction after 2008 was based on increased competition in the market.

Table 5. The concentration of mobile market (users) in Serbia (2003-2014)

\begin{tabular}{|r|r|r|r|r|r|}
\hline \multirow{2}{*}{ Year } & \multicolumn{2}{|c|}{ Market shares (users) } & \multirow{2}{*}{ HHI } & \multirow{2}{*}{ Growth rate } \\
\cline { 2 - 4 } & MTS & Telenor & \multicolumn{1}{c|}{ VIP } & & \\
\hline 2003 & $55.10 \%$ & $44.90 \%$ & & 5,052 & $-0.54 \%$ \\
\hline 2004 & $53.50 \%$ & $46.50 \%$ & & 5,025 & $0.25 \%$ \\
\hline 2005 & $54.30 \%$ & $45.70 \%$ & & 5,037 & $5.86 \%$ \\
\hline 2006 & $62.90 \%$ & $37.10 \%$ & & 5,332 & $-10.75 \%$ \\
\hline 2007 & $59.40 \%$ & $34.60 \%$ & $6.00 \%$ & 4,759 & $-1.58 \%$ \\
\hline 2008 & $58.93 \%$ & $31.94 \%$ & $9.13 \%$ & 4,684 & $-3.50 \%$ \\
\hline 2009 & $59.70 \%$ & $28.70 \%$ & $11.60 \%$ & 4,520 & $-6.22 \%$ \\
\hline 2010 & $56.00 \%$ & $30.30 \%$ & $13.70 \%$ & 4,239 & $-5.05 \%$ \\
\hline 2011 & $53.10 \%$ & $30.80 \%$ & $16.13 \%$ & 4,025 & $-9.17 \%$ \\
\hline 2012 & $45.80 \%$ & $33.90 \%$ & $20.30 \%$ & 3,656 & $-1.64 \%$ \\
\hline 2013 & $44.80 \%$ & $33.30 \%$ & $21.90 \%$ & 3,596 & $-0.33 \%$ \\
\hline 2014 & $44.56 \%$ & $33.27 \%$ & $22.17 \%$ & 3,584 & \\
\hline
\end{tabular}

Source: RATEL. 2015. An Overview of the Telecom and Postal Services Market in the Republic of Serbia in 2014 and authors' calculation

The market is still highly concentrated based on European regulatory guidelines that classify the market with $\mathrm{HHI}$ above 2,500 as the highly concentrated market. Nevertheless, it should be emphasized that the lowest possible level of $\mathrm{HHI}$ for 3 companies that have equal market shares is 3,332.67 and that the actual level of $\mathrm{HHI}$ has almost reached that level. Further reduction of $\mathrm{HHI}$ requires issuing one more license. But since the market has reached stable equilibrium, the fourth license would be of low 
Trifunović D., Mitrović Đ.: Network Externalities in Telecommunication Industry: An...

value and bearing in mind the strong network externalities effect in this market, the newcomer would be faced with immense challenge to reach critical mass of users. From regulatory point of view, this level of $\mathrm{HHI}$ is of no concern, since prices were lowered substantially and consumers' surplus was considerably increased. This example shows us that regulatory policy should not be based only on concentration measures and further analysis of actual behaviour of competitors is necessary. ${ }^{18}$

Market shares and $\mathrm{HHI}$ index based on total revenues from mobile services are recalculated, which shows lower concentration than $\mathrm{HHI}$ measured on the number of subscribers. Hence, $\mathrm{HHI}$ measured on the number of subscribers systematically over estimates concentration in the market and, $\mathrm{HHI}$ measured on total revenues from mobile services provides more correct image. The difference between the two measures stems from MTS's lower outgoing traffic per user.

Table 6. The concentration of mobile market (revenues) in Serbia (2009-2014)

\begin{tabular}{|c|c|c|c|c|c|c|}
\hline \multirow{2}{*}{ Year } & \multicolumn{3}{|c|}{ Share in the total revenues } & \multirow{2}{*}{$\begin{array}{c}\begin{array}{c}\mathrm{HHI} \\
\text { (revenues) }\end{array}\end{array}$} & \multirow{2}{*}{$\begin{array}{c}\text { HHI } \\
\text { (users) }\end{array}$} & \multirow{2}{*}{ Difference } \\
\hline & MTS & Telenor & VIP & & & \\
\hline 2009 & $50.70 \%$ & $40.50 \%$ & $8.80 \%$ & 4,288 & 4,520 & -232 \\
\hline 2010 & $43.70 \%$ & $42.40 \%$ & $13.90 \%$ & 3,901 & 4,239 & -338 \\
\hline 2011 & $38.80 \%$ & $43.60 \%$ & $17.60 \%$ & 3,716 & 4,025 & -309 \\
\hline 2012 & $38.10 \%$ & $42.40 \%$ & $19.50 \%$ & 3,630 & 3,656 & -26 \\
\hline 2013 & $37.00 \%$ & $41.00 \%$ & $22.00 \%$ & 3,534 & 3,596 & -62 \\
\hline 2014 & $36.80 \%$ & $40.28 \%$ & $22.90 \%$ & 3,501 & 3,584 & -83 \\
\hline
\end{tabular}

Source: Authors' calculation based on RATEL reports

In the following discussion market share based on number of users will be used unless otherwise stated.

\subsection{Reduction of switching costs and call externalities}

One more aspect is important for understanding general price pattern in this market. In 2011, regulatory authority adopted the policy of mobile phone number portability (MPNP). The effect of this policy is reduction of users' switching costs. The price reduction that followed adoption of such policy is not that obvious based on average price that includes prices for on-net and off-net calls. This issue will be discussed in more detail below in section on price discrimination. At this point it is worth emphasizing that the number of

\footnotetext{
${ }^{18}$ See Ristić and Trifunović (2014) for more details concerning this issue and Miljković, Tanasković and Filipović (2013) as well as Babić, Zildžović and Lončar (2015).
} 
Trifunović D., Mitrović Đ.: Network Externalities in Telecommunication Industry: An...

users using this option has grown and it has reached almost $1 \%$ of all users in the last year. However, it seems that in the last year the distribution of operators that received these users is approximately evenly distributed.

This policy aims to promote competition and to increase the subscriber base of small companies. Based on the evidence from Hong Kong, Shi, Chiang and Ree (2006) claim that this policy didn't achieve its objective and it gave boost to companies with large market shares because users with reduced switching costs opted to subscribe to large network to benefit from cheaper on-net calls.

Table 7. The total ported mobile numbers in Serbia (2011-2014)

\begin{tabular}{|c|r|r|}
\hline Year & Number of ported numbers (annually) & \multicolumn{2}{|c|}{$\%$ of all users } \\
\hline 2011 & 37,037 & $0.36 \%$ \\
\hline 2012 & 77,785 & $0.77 \%$ \\
\hline 2013 & 85,673 & $0.85 \%$ \\
\hline 2014 & 99,142 & $0.98 \%$ \\
\hline
\end{tabular}

Source: RATEL. 2015. An Overview of the Telecom and Postal Services Market in the Republic of Serbia in 2014 and authors' calculation

There is no support for that claim in the data. The company with the largest market share, MTS, reduced its market share from $53.1 \%$ to $44.56 \%$ after the adoption of this regulatory policy in 2011 and the company with the smallest market share VIP increased its market share from $16.13 \%$ in 2011 to $22.17 \%$ in 2014. Hence, MPNP has proven as the pro-competitive policy in Serbia.

Table 8. The share of pre and post-paid users (2007-2014)

\begin{tabular}{|r|r|r|r|r|r|r|}
\hline \multirow{2}{*}{ Year } & \multicolumn{2}{|c|}{ MTS } & \multicolumn{2}{c|}{ Telenor } & \multicolumn{2}{c|}{ VIP } \\
\cline { 2 - 7 } & Prepaid & Postpaid & Prepaid & Postpaid & Prepaid & Postpaid \\
\hline 2007 & $80.30 \%$ & $19.70 \%$ & $77.90 \%$ & $22.10 \%$ & $89.00 \%$ & $11.00 \%$ \\
\hline 2008 & $79.73 \%$ & $20.27 \%$ & $74.98 \%$ & $25.02 \%$ & $85.66 \%$ & $14.34 \%$ \\
\hline 2009 & $77.23 \%$ & $22.77 \%$ & $72.06 \%$ & $27.94 \%$ & $82.33 \%$ & $17.68 \%$ \\
\hline 2010 & $74.16 \%$ & $25.84 \%$ & $65.24 \%$ & $34.76 \%$ & $65.00 \%$ & $35.00 \%$ \\
\hline 2011 & $73.59 \%$ & $26.41 \%$ & $62.32 \%$ & $37.68 \%$ & $58.00 \%$ & $42.00 \%$ \\
\hline 2012 & $62.01 \%$ & $37.99 \%$ & $57.45 \%$ & $42.55 \%$ & $52.80 \%$ & $47.20 \%$ \\
\hline 2013 & $57.33 \%$ & $42.67 \%$ & $53.56 \%$ & $46.44 \%$ & $49.20 \%$ & $50.80 \%$ \\
\hline 2014 & $52.82 \%$ & $47.18 \%$ & $51.61 \%$ & $48.39 \%$ & $49.60 \%$ & $50.40 \%$ \\
\hline
\end{tabular}

Source: Authors' calculation based on RATEL and mobile operators' annual business and financial reports

This policy is becoming more important with the increase of the number of post-paid users because these users have higher switching costs than pre- 
Trifunović D., Mitrović Đ.: Network Externalities in Telecommunication Industry: An...

paid users. Prior to the adoption of this policy, these consumers were lockedin with current operator who had the possibility to exploit this position through higher prices (Klemperer, 1995). Table 8 shows us that the overall share of post-paid users continued to increase after 2011 as well as the share of these users for each operator individually.

One more insight is interesting form the previous table. Pre-paid users are those who are the most likely to benefit from call externalities when user benefits from receiving free calls from other users. As the relative proportion of these users declines in competitors' networks, operator should reduce its off-net price, because high off-net price serves as an instrument to internalize call externalities according to Hoering (2007). It will be shown soon that this was indeed the case in Serbia. Second, the company that last entered the market, VIP, in the first years of its operations had considerably more pre-paid than post-paid users. It can be inferred that the entrant in the market was attractive for users who mainly benefited from call externalities since at the time of entry off-net calls were quite expensive. Call externalities will be examined in more detail by calculating the average annual traffic per user.

Table 9. Total outgoing traffic in mobile communications (2007-2014)

\begin{tabular}{|c|c|c|c|c|c|c|c|c|}
\hline \multirow[b]{2}{*}{ 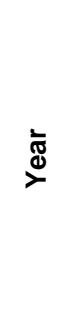 } & \multirow{2}{*}{ 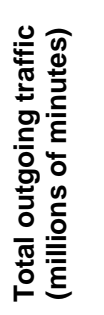 } & \multirow{2}{*}{ 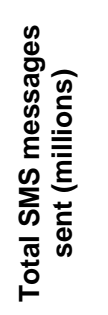 } & \multicolumn{3}{|c|}{$\begin{array}{l}\text { Outgoing traffic } \\
\text { per user }\end{array}$} & \multicolumn{3}{|c|}{$\begin{array}{c}\text { SMS messages sent per } \\
\text { user }\end{array}$} \\
\hline & & & $\stackrel{\mathscr{N}}{\Sigma}$ & 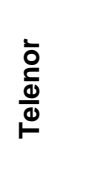 & $\stackrel{n}{>}$ & $\stackrel{\infty}{\Sigma}$ & 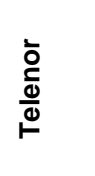 & $\stackrel{n}{>}$ \\
\hline 2009 & 8,203 & 9,290 & 738 & 1,041 & 764 & 959 & 797 & 1,172 \\
\hline 2010 & 8,839 & 9,704 & 700 & 1,232 & 917 & 940 & 843 & 1,435 \\
\hline 2011 & 10,147 & 9,618 & 814 & 1,310 & 998 & 911 & 917 & 1,107 \\
\hline 2012 & 11,719 & 10,158 & 1,025 & 1,401 & 1,098 & 1,078 & 928 & 1,002 \\
\hline 2013 & 13,678 & 10,764 & 1,202 & 1,532 & 1,390 & 1,017 & 1,036 & 1,206 \\
\hline 2014 & 14,863 & 10,290 & 1,308 & 1,637 & 1,519 & 880 & 1,039 & 1,244 \\
\hline
\end{tabular}

Source: Authors' calculation based on RATEL reports

It is evident that outgoing traffic as well as total number of SMS are on steady increase. In the first year of observation, 2009, VIP had surpassed one of the incumbents, MTS, by outgoing traffic per user, and in that year users of VIP didn't benefit more from call externalities than users of MTS. From 2009, VIP 
Trifunović D., Mitrović Đ.: Network Externalities in Telecommunication Industry: An...

has increased outgoing traffic per user by $98.82 \%$ which is consistent with larger share of post-paid users. In the same period, Telenor increased outgoing traffic per user by $57.25 \%$, while the company with the largest number of users, MTS, had an increase of $77.24 \%$, but is has the lowest level of outgoing calls and SMS per user in the market.

It is somehow paradoxical that in 2014 MTS users are those that mostly benefited from call externalities, but it is consistent with the fact that this company has the largest share of pre-paid users in the last year of observation. This is one more indicator of the lower competitiveness of MTS compared to other two rivals and it can be inferred that users of MTS have on average lower purchasing power.

Table 10. Average revenues from mobile telephony services per user (EUR/user, 2007-2013)

\begin{tabular}{|c|c|c|c|c|c|c|c|c|}
\hline \multirow{2}{*}{ Year } & \multicolumn{2}{|c|}{$\begin{array}{l}\text { Post-paid services } \\
\text { traffic }^{\star}\end{array}$} & \multicolumn{2}{|c|}{$\begin{array}{l}\text { Post-paid services } \\
\text { subscription* }\end{array}$} & \multicolumn{2}{|c|}{$\begin{array}{l}\text { Pre-paid } \\
\text { services }^{\star \star}\end{array}$} & \multicolumn{2}{|c|}{ Interconnection ${ }^{\star \star \star}$} \\
\hline & MTS & Telenor & MTS & Telenor & MTS & Telenor & MTS & Telenor \\
\hline 2007 & 75.26 & 133.81 & 45.11 & 54.20 & 47.99 & 54.94 & 6.42 & 25.66 \\
\hline 2008 & 81.35 & 132.86 & 66.76 & 66.56 & 46.99 & 53.07 & 7.61 & 25.81 \\
\hline 2009 & 65.17 & 113.35 & 49.58 & 65.85 & 38.36 & 48.04 & 7.02 & 24.81 \\
\hline 2010 & 51.15 & 77.42 & 40.01 & 58.95 & 33.01 & 49.28 & 9.01 & 20.85 \\
\hline 2011 & 46.67 & 74.55 & 45.38 & 70.09 & 32.09 & 44.12 & 10.53 & 25.92 \\
\hline 2012 & 36.68 & 54.36 & 41.24 & 66.46 & 35.49 & 37.25 & 12.24 & 24.54 \\
\hline 2013 & 38.13 & 44.41 & 42.90 & 74.29 & 30.27 & 36.16 & 12.89 & 25.86 \\
\hline
\end{tabular}

Source: Authors' calculation based on mobile operators' audited annual financial statements

By comparing two incumbents in the market, it is obvious that both of them had steady fall of revenue per post-paid user (Table 10), but this effect is based on the fact that subscription packages include more minutes for on-net and off-net calls and users choose package according to their needs. At the same time, one part of the fall in revenue from 2007 might be explained by fiercer competition upon entry of VIP. Concerning pre-paid users, it can be identified that both companies had lower revenue from these users, with MTS having lower revenue per pre-paid user. This result strengthens the earlier finding that MTS's users, and especially its pre-paid market segment, are those who benefit the most from call externalities. One more finding of Shi, 
Trifunović D., Mitrović Đ.: Network Externalities in Telecommunication Industry: An...

Chiang and Ree (2006) can be checked with the data sample. They claim that subscription fee should decline upon reduction of switching costs. It was determined that this was not the case for one incumbent Telenor. Moreover, an increase in subscription fee per user in 2011 and also in 2013 was identified for that company. For the other incumbent, MTS, a slight increase in subscription fee per user was identified, and fall in subscription revenue per user thereafter. Nevertheless, the model of Shi, Chiang and Ree (2006) claims that reduction of subscription fee of large company should attract new users from small companies and increase its market share. It was shown previously that this was not the case with MTS who constantly loses its market share despite lower subscription fee per user that the company charges.

Comparison of average interconnection revenue per user reveals unexpected results since access revenue per user of Telenor is substantially higher than MTS. To interpret the data properly, it should be emphasized that Telekom Srbija has its own network of fixed telephony that was in monopoly position until recently and that calls originating from fixed telephony and terminating on MTS network are not subject to access charge. On the other hand, calls that originate from fixed telephony network and terminate on Telenor's network are charged access fee and this fact explains considerable difference in access revenue per user.

Furthermore, Shi, Chiang and Ree (2006) claim that small company's profit should decline upon introduction of MPNP while large company's profit should increase. This conclusion is checked in Serbian market.

Table 11. Financial performance indicators of mobile operators in Serbia (2010-2014)

\begin{tabular}{|l|r|r|r|r|r|r|r|r|r|}
\hline \multirow{2}{*}{ Year } & \multicolumn{4}{|c|}{ EBIT (mil. EUR) } & \multicolumn{3}{c|}{ EBITDA (mil. EUR) } & \multicolumn{3}{c|}{ Net Profit (mil. EUR) } \\
\cline { 2 - 10 } & MTS & Telenor & \multicolumn{1}{c|}{ VIP } & \multicolumn{1}{c|}{ MTS } & Telenor & \multicolumn{1}{c|}{ VIP } & \multicolumn{1}{c|}{ MTS } & Telenor & \multicolumn{1}{c|}{ VIP } \\
\hline $\mathbf{2 0 1 0}$ & 178.0 & 52.5 & -47.1 & 342.4 & 175.1 & 0 & 153.2 & 67.0 & -110.2 \\
\hline $\mathbf{2 0 1 1}$ & 185.3 & 79.9 & 21.1 & 355.8 & 155.7 & 31.5 & 218.5 & 96.7 & -24.4 \\
\hline $\mathbf{2 0 1 2}$ & 140.3 & 98.0 & -18.4 & 288.9 & 138.8 & 49.0 & 99.4 & 102.5 & -76.7 \\
\hline $\mathbf{2 0 1 3}$ & 134.2 & 106.9 & -8.6 & 279.1 & 146.2 & 64.0 & 135.5 & 114.5 & -9.3 \\
\hline $\mathbf{2 0 1 4}$ & 133.6 & 109.2 & -2.9 & 274.4 & 154.1 & 64.0 & 143.9 & 109.3 & $\mathrm{n} / \mathrm{a}$ \\
\hline
\end{tabular}

Source: Mobile operators' annual business and financial reports

Table 11 shows that EBITDA declined after reduction of switching costs for company with the largest number of users, MTS. The other incumbent's EBITDA exhibits non-monotonic pattern. In 2011 it fell and in 2013 it started rising. The company with the smallest market share, VIP, had a steady increase of its EBITDA with reduced switching costs. Net profit of MTS was 
Trifunović D., Mitrović Đ.: Network Externalities in Telecommunication Industry: An...

lower after MPNP policy was adopted and it never reached the level in 2011. Telenor's net profit was slightly increased, while VIP's loss was declining in the same period. This loss was due to large investments of establishing its own network. Nevertheless, even based on the net profit it is evident that the smallest company's net result was improved after reduction of switching costs which is in sharp contrast with the previous theoretical finding.

Quite different conclusions in Serbia than in Hong-Kong could be explained with different pricing strategies. While in Hong-Kong at the time of the analysis two-part tariffs were used, in Serbia post-paid users decide on package tailored to number of minutes they need and they rarely need to pay additional minutes. This implies that on-net discounts became less important and as it will be shown soon; it was the case for users of MTS that didn't reduce its onnet price considerably until 2014 .

\subsection{Access revenue}

The upper bound of access price in Serbia is regulatory determined and operators are free to choose access price in the interval from 0 to upper bound. In practice, this constraint is binding and operators set access price equal to upper bound, that was regulatory determined at $4.8 \mathrm{RSD} /$ minute in 2013, $3.95 \mathrm{RSD} / \mathrm{minute}$ in 2014 and $3.43 \mathrm{RSD} /$ minute in 2015. It is evident that the regulatory determined upper bound exhibits downward trend. By using the OECD methodology for calculation of price of typical basket for digital mobile services, the average payment per user for interconnection by the three operators in last 3 years was estimated. ${ }^{19}$

Table 12. Payments for interconnection per user (EUR/user, 2007-2013)

\begin{tabular}{|l|c|c|c|}
\hline Operator & $\mathbf{2 0 1 2}$ & $\mathbf{2 0 1 3}$ & $\mathbf{2 0 1 4}$ \\
\hline MTS & 10.43 & 12.24 & 10.57 \\
\hline Telenor & 14.27 & 13.54 & 13.23 \\
\hline VIP & 11.18 & 12.29 & 12.27 \\
\hline
\end{tabular}

Source: Authors' calculation

Table 12 shows that MTS has the lowest payment for interconnection. This result could be also explained by the fact that MTS belongs to Telekom group that has its fixed telephony operator. However, the relative share of calls from

${ }^{19}$ The OECD (2006) methodology for calculation of prices of baskets of digital mobile services proposes a division of total outgoing calls on calls that terminate on: fixed network (local and national calls), mobile network (on-net and off-net calls) and voice mail. We used the "medium user" basket as a base for distribution of total outgoing minutes at operator level (according to RATEL reports) per different types of calls. 
Trifunović D., Mitrović Đ.: Network Externalities in Telecommunication Industry: An...

mobile to fixed network is relatively small and smaller than the share of calls from fixed to mobile network. This pattern of calls implies that the lower payment of MTS to other operators for access charges might be a consequence of lower level of outgoing traffic from this network and higher level of call externalities that users of this network experience.

\subsection{Price discrimination}

In this section analysis of price discrimination when operators charge higher

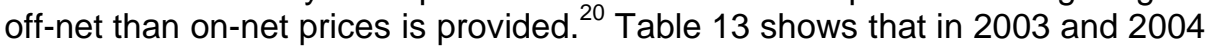
Telenor used uniform prices and started with slight price discrimination between off-net and on-net calls in 2005. From 2007, after entry of VIP, incumbents maintained nearly constant ratio of prices of on-net and off-net calls with a slight increase in price discrimination for Telenor in 2010. Off-net calls are more expensive since the cost of this call includes access charge that one operator has to pay to other for terminating calls that originate from its network. This pricing strategy of operators clearly overpriced on-net calls extracting the consumer's surplus by exploiting consumers' high switching costs due to lock-in. It seems that after the entry of VIP in the market, incumbents didn't engage in predatory behaviour aimed to deter the entrant from the market by increasing the difference between off-net and on-net prices as in Calzada and Valletti (2008). It can be inferred that incumbents adopted the entrant by having belief that it is a small-scale entry, and have found that is more profitable to exploit the locked-in consumers by charging high on-net prices than to engage in predatory behaviour by deterring entry. Incumbents' reaction to entry was limited to higher differentiation trough new packages. On the other hand, the entrant started with price discrimination in 2008 and increased price discrimination substantially in 2010. Concerning this strategic pricing aspect, entrant started earlier being more aggressive than incumbents and particularly MTS who didn't engage in higher price discrimination even after reduction of switching costs in 2011 . This could be

\footnotetext{
20 The price calculation for Telenor was based on „Start” (data before 2010) and basic "Prenesi" post-paid packages (data after 2010). The price calculation for MTS was based on "Hello" (data before 2013), basic "Bel" (2013) and "Prica" (2014) post-paid packages. The price calculation for VIP was based on "Postpaid tarifa 60" (data before 2011) and "Standard 100" post-paid packages (data 2011-2014). Regarding "Prenesi", "Bel", "Prica" and "Standard" packages, the base for calculation of on and off-net calls prices was the subscription fee and total number of available minutes for off and onnet calls. The price of off-net calls is calculated as ratio between subscription fee and total available off-net minutes, while the price of on-net calls is calculated as ratio between subscription fee and total available off-net plus on-net minutes (under assumption that user can spend the all available minutes in package only on on-net calls).
} 
Trifunović D., Mitrović Đ.: Network Externalities in Telecommunication Industry: An...

one of the reasons for the reduction in MTS's market share and increase in VIP's market share.

Table 13. Prices for on-net and off-net outgoing calls (2003-2014)

\begin{tabular}{|c|c|c|c|c|c|c|c|c|c|}
\hline \multirow{3}{*}{ Year } & \multicolumn{2}{|c|}{ Telenor } & \multicolumn{2}{|c|}{ MTS } & \multicolumn{2}{|c|}{ VIP } & \multirow{2}{*}{$\begin{array}{c}\text { Telenor } \\
\text { On/Off }\end{array}$} & \multirow{2}{*}{$\begin{array}{c}\text { MTS } \\
\text { On/Off }\end{array}$} & \multirow{2}{*}{$\begin{array}{c}\text { VIP } \\
\text { On/Off }\end{array}$} \\
\hline & On-net & Off-net & On-net & Off-net & On-net & Off-net & & & \\
\hline & \multicolumn{6}{|c|}{ EUR/min } & \multicolumn{3}{|c|}{$\%$} \\
\hline 2003 & 0.203 & 0.203 & & & & & 100.00 & & \\
\hline 2004 & 0.175 & 0.175 & & & & & 100.00 & & \\
\hline 2005 & 0.119 & 0.143 & & & & & 83.19 & & \\
\hline 2006 & 0.056 & 0.113 & & & & & 49.37 & & \\
\hline 2007 & 0.043 & 0.087 & 0.041 & 0.086 & & & 49.14 & 48.28 & \\
\hline 2008 & 0.042 & 0.085 & 0.041 & 0.084 & 0.085 & 0.085 & 49.14 & 48.28 & 100.00 \\
\hline 2009 & 0.036 & 0.074 & 0.035 & 0.073 & 0.037 & 0.074 & 49.14 & 48.28 & 49.44 \\
\hline 2010 & 0.021 & 0.068 & 0.032 & 0.066 & 0.009 & 0.068 & 30.75 & 48.28 & 13.21 \\
\hline 2011 & 0.021 & 0.068 & 0.032 & 0.067 & 0.009 & 0.068 & 30.75 & 48.28 & 13.21 \\
\hline 2012 & 0.005 & 0.053 & 0.029 & 0.060 & 0.005 & 0.070 & 10.00 & 48.28 & 6.84 \\
\hline 2013 & 0.005 & 0.053 & 0.035 & 0.043 & 0.005 & 0.070 & 10.00 & 80.78 & 6.84 \\
\hline 2014 & 0.001 & 0.059 & 0.005 & 0.051 & 0.005 & 0.067 & 2.00 & 9.02 & 7.34 \\
\hline
\end{tabular}

Source: Authors' calculation based on official operators' post-paid offers

Recall that Hoering (2007) postulates that higher off-net prices could reflect an attempt to internalize call externalities rather than predatory behaviour. The table reveals moderate decline of off-net prices accompanied with higher share of post paid users and consequently with lower call externalities. It should be also mentioned that this reaction was not symmetric. By comparing Tables 7 and 13, it can be inferred that from 2009-2014 MTS and Telenor increased their share of post paid users from $22,77 \%$ to $47,18 \%$ and from $27,94 \%$ to $48,39 \%$, respectively and VIP retained almost constant price for off-net calls in the same period. On the other hand, MTS reduced its off-net price by $30 \%$ in the same period and Telenor by $20 \%$. It is unexpected that MTS lowered its off-net price to the greatest extent bearing in mind that its users benefit the most from call externalities.

Concerning the second important event in the market, MPNP adopted in 2011, it is evident that at the onset of this event in 2010 Telenor increased price discrimination by reducing its price for on-net calls. In the following year, when MPNP policy was adopted, MTS stayed passive and maintained the same ratio of on-net to off-net prices, while the late comer, VIP, started with considerable price discrimination even before 2011. In 2012 the degree of price discrimination of Telenor became comparable to that of VIP, while MTS still remained passive. It was not before 2014 when MTS changed its 
Trifunović D., Mitrović Đ.: Network Externalities in Telecommunication Industry: An...

behaviour and engaged in fiercer competition which is consistent with the fact that an increasing number of users (around $1 \%$ of the subscription base) opted to switch the operator and keep their number.

Recall that from 2011, the overall number of subscribers remained nearly constant and the price reduction of on-net calls was not caused by network externalities effect. The main reason for this price reduction was fierce competition due to reduced switching costs. By comparing on-net prices in 2011 and 2014, it can be determined that on net-price of Telenor in 2014 was only $6.54 \%$ of the level in 2011 , for MTS it was $16.36 \%$, and for VIP $63 \%$. Concerning off-net prices, data reveal that these prices were not considerably reduced by incumbents after entry of VIP in 2007. After the adoption of MPNP policy, Telenor and MTS reduced their off-net prices followed by an increase in 2014, while VIP increased its off-net price slightly. As was previously said, the pattern of off-net prices of MTS and Telenor could be more related to access charge and reduction of call externalities. The strategy of VIP's off-net prices could be related to the increased subscription base for this company and larger share of on-net calls among its users. The concern for maintaining subscriber base from competitors became more important for VIP than attracting new users. Prices of on-net calls were reduced in the same period, and as a consequence price discrimination was more pronounced with the ratio of on-net to off-net price in 2014 at the level of $2 \%$ for Telenor, $9 \%$ for MTS and $7.34 \%$ for VIP. This price discrimination is a signal of more intense competition which was also supported in the data with the fact that more users decide to change their operator. These findings are also consistent with theory of Laffont, Rey and Tirole (1998b) and Calzada and Valletti (2008) who claim that more intense competition results in larger price discrimination. Since the number of users remained almost constant after 2011 consumer's welfare was not increased due to network externality effect. At the same time, the price of on-net calls was substantially reduced, while the price of off-net calls remained constant for entrant and was reduced for incumbents, and consumer's surplus was unambiguously increased. Therefore, the policy of mobile phone number portability was beneficial for consumers and the reduction of on-net prices was not based solely on cost reduction, which is evident if we compare the pattern of off-net prices in the same period, and costs of on-net call constitute also a part of costs of off-net calls. Hence, this reduction of prices for on-net calls indicate a rent that was captured by incumbents prior to 2011 due to consumer's high switching costs. It was explained previously that MPNP policy was also pro-competitive and quite different effects were identified from this measure in Serbia than that suggested by Shi, Chiang and Ree (2006). 
Trifunović D., Mitrović Đ.: Network Externalities in Telecommunication Industry: An...

\subsection{On the receiver pays principle}

The receiver pays principle when receiver pays for calls that he receives is applied in the USA in domestic traffic. In the majority of European countries, as well as in Serbia, receiver pays only for roaming services. According to López (2011) the main reason for this difference is that access charges in the US are very low and below the cost of call termination, while in Europe access charges are considerably higher. In the terminology of Jeon, Laffont and Tirole (2004) users experience direct externalities when they receive calls but they also experience pecuniary externalities by paying more for receiving calls. Therefore, roaming service is specific and the length of call is determined by both caller and receiver. Table 14 provides data about roaming prices for outgoing and incoming calls for the three operators for some most popular destinations for summer vacation when the roaming service is dominantly used by majority of subscribers who use roaming. The prices are from 2015 and are calculated in EUR. It can be seen that MTS and Telenor price discriminate between outgoing and incoming roaming calls with similar tariffs, while VIP uses uniform pricing strategy. Compared to other two networks users of VIP in general pay less for outgoing roaming calls, but also pay considerably more for receiving calls than users of other networks. Thus, users of VIP are subject to the highest level of pecuniary externalities and the volume of traffic for these users in roaming is more often determined by receivers than by callers. For the furthest destinations such as Tunis or Egypt, users of VIP are subject to 2.2 (2) times larger level of pecuniary externalities than users of MTS (Telenor).

Table 14. Roaming prices for Serbian operators' users in selected countries (EUR/min, 2015)

\begin{tabular}{||l||c|c||c|c||c|c||}
\hline \multirow{2}{*}{\multicolumn{1}{|c||}{ Country }} & \multicolumn{2}{c||}{ MTS } & \multicolumn{2}{c||}{ Telenor } & \multicolumn{2}{c||}{ VIP } \\
\cline { 2 - 7 } & $\begin{array}{c}\text { outgoing } \\
\text { call }\end{array}$ & $\begin{array}{c}\text { incoming } \\
\text { call }\end{array}$ & $\begin{array}{c}\text { outgoing } \\
\text { call }\end{array}$ & $\begin{array}{c}\text { incoming } \\
\text { call }\end{array}$ & $\begin{array}{c}\text { outgoing } \\
\text { call }\end{array}$ & $\begin{array}{c}\text { incoming } \\
\text { call }\end{array}$ \\
\hline \hline Montenegro & 0.14 & 0.08 & 0.08 & 0.00 & 0.35 & 0.10 \\
\hline Croatia & 0.85 & 0.30 & 0.91 & 0.37 & 0.82 & 0.82 \\
\hline Greece & 0.85 & 0.30 & 0.91 & 0.37 & 0.82 & 0.82 \\
\hline Turkey & 1.24 & 0.35 & 1.33 & 0.46 & 0.82 & 0.82 \\
\hline Tunis & 2.99 & 0.75 & 3.15 & 0.83 & 1.65 & 1.65 \\
\hline Egypt & 2.99 & 0.75 & 3.15 & 0.83 & 1.65 & 1.65 \\
\hline
\end{tabular}

Source: Authors' calculation based on official operators' post-paid offers

One more form of externalities could be identified for networks that discriminate between outgoing and incoming roaming calls. Namely, users can save by receiving calls instead of making calls that are more expensive. 
Trifunović D., Mitrović Đ.: Network Externalities in Telecommunication Industry: An...

This type of externalities parallels with call externalities although they are much smaller in scale due to the fact that receiver is more likely to hang up. For the most popular tourist destination, Greece, call externalities in roaming for users of MTS and Telenor are 0.55 and 0.54 EUR per minute, respectively. The further the destination, the higher the level of these externalities for users of MTS and Telenor. For Turkey and Egypt, the externalities are 2.24 EUR per minute for MTS users and 2.32 EUR for Telenor users. Users of VIP don't benefit from call externalities in roaming. Needless to say, revenues that operators receive from roaming service are constantly declining with the widespread use of applications that offer free communications in roaming such as "WhatsApp" and "Viber".

In order to obtain more precise image about roaming tariffs, average price of outgoing calls for two regions are calculated: Balkans and the rest of Europe. There is no clear upward or downward trend of outgoing roaming prices for MTS and Telenor users in both regions and for VIP users, prices were slightly reduced. Prices of outgoing roaming calls are quite expensive compared to off-net prices for domestic outgoing calls. The access charge for interconnection in international traffic is much higher than access charge in domestic traffic, but these prices also contain high margins above costs of call transport and termination. The evidence for the last claim could be found in the mutual agreement among the governments in Balkan region to reduce regional roaming tariffs. Operators in the region were forced to reduce their margins with this agreement.

Table 15. Average price of outgoing calls in roaming (EUR/min, 2010-2015)

\begin{tabular}{|c|c|c|c|c|c|c|c|c|c|c|c|c|}
\hline \multirow[b]{2}{*}{ Year } & \multicolumn{3}{|c|}{$\begin{array}{l}\text { Outgoing call } \\
\text { Balkan roaming }\end{array}$} & \multicolumn{3}{|c|}{$\begin{array}{l}\text { Outgoing call } \\
\text { Europe roaming }\end{array}$} & \multicolumn{3}{|c|}{$\begin{array}{l}\text { Roaming/National } \\
\text { Prices Ratio Balkan }\end{array}$} & \multicolumn{3}{|c|}{$\begin{array}{l}\text { Roaming/National } \\
\text { Prices Ratio Europe }\end{array}$} \\
\hline & $\stackrel{\infty}{\Sigma}$ & 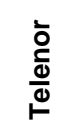 & $\stackrel{n}{>}$ & $\stackrel{\infty}{\Sigma}$ & $\frac{\grave{o}}{\stackrel{c}{\Phi}}$ & $\stackrel{\varrho}{>}$ & $\begin{array}{l}\stackrel{Ð}{\varrho} \\
\stackrel{5}{\Sigma}\end{array}$ & 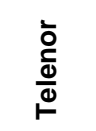 & $\begin{array}{l}\widehat{\varrho} \\
\stackrel{\circ}{>}\end{array}$ & $\frac{\widehat{\varrho}}{\stackrel{\infty}{E}}$ & 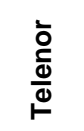 & $\begin{array}{l}\stackrel{\circ}{\varrho} \\
\frac{a}{>}\end{array}$ \\
\hline 2010 & 0.63 & 0.97 & 1.13 & 1.22 & 1.37 & 2.05 & 9.40 & 17.69 & 16.7 & 18.02 & 24.98 & 30.34 \\
\hline 2011 & 0.98 & 0.98 & 0.98 & 0.98 & 1.42 & 1.23 & 14.37 & 27.60 & 14.36 & 14.37 & 40.03 & 17.95 \\
\hline 2012 & 1.18 & 0.90 & 0.90 & 1.19 & 1.30 & 1.12 & 22.29 & 28.06 & 12.87 & 22.50 & 40.70 & 16.09 \\
\hline 2013 & 0.90 & 0.90 & 0.90 & 1.35 & 1.30 & 1.12 & 16.95 & 27.61 & 12.87 & 25.42 & 40.04 & 16.09 \\
\hline 2014 & 0.87 & 0.87 & 0.87 & 1.28 & 1.26 & 1.08 & 14.68 & 16.96 & 12.87 & 21.58 & 24.60 & 16.09 \\
\hline 2015 & 0.85 & 0.91 & 0.82 & 1.24 & 1.33 & 0.82 & 14.29 & 17.86 & 12.20 & 21.01 & 25.99 & 12.20 \\
\hline
\end{tabular}

Source: Authors' calculation based on official operators' post-paid offers 
Trifunović D., Mitrović Đ.: Network Externalities in Telecommunication Industry: An...

Returning to Table 15, it can be figured out that from 2011 Telenor has the highest ratio of the price of outgoing roaming calls from both Balkans and Europe to domestic off-net calls indicating the highest margin that these prices reflect. MTS is the second most expensive company according to this ratio, while VIP is the cheapest operator according to this criterion. However, price-cap regulation for roaming tariffs was not successful in EU according to Ambjørnsen et al (2011). The impact of this regulation was that all operators adopted uniform roaming prices with binding caps and the price competition that existed before vanished.

\section{Conclusion}

The analysis of network externalities in Serbian mobile phone telecommunications market has revealed many interesting aspects. First of all, network externalities have increased the market size considerably. The unexpected result is that users of the largest company benefit the most from call externalities. MPNP policy was pro-competitive which is quite different conclusion from previous research. When conclusions from theoretical models were rejected, models need to be reconstructed based on new assumptions that could be supported by actual behaviour of operators. One possible avenue for further research might be the reconstruction of the model with MPNP since pricing strategy in this market at present is quite different from pricing strategy at the time when the model was constructed.

The additional contribution of the paper is related to welfare implications of strategic behaviour in this market. It was shown that the entry of third operator as well as MPNP were welfare improving. This market is specific due to the specific nature of users' utility function and some regulatory policies that have been successful in other markets may fail in this market. For instance, the behaviour that could be considered as predatory in many markets might be the only possible strategy in this market that enables firm's survival. Therefore, more research in this field is needed to better understand the nature of this market and especially research about Serbian and other regional markets where these analyses should be particularly encouraged.

\section{References}

Ambjørnsen, T., Foros, $\varnothing$, \& Wasenden, O-C. (2011). Customer Ignorance, Price-cap Regulation, and Rent-seeking in Mobile Roaming. Information Economics and Policy, 23, 27-36. doi:10.1016/j.infoecopol.2010.03.002 
Trifunović D., Mitrović Đ.: Network Externalities in Telecommunication Industry: An...

Babić, A. Zildžović, E \& Lončar, D. (2015). Testing for Competition in Serbian Banking Industry: the Panzar-Rosse Approach, Industrija, 43(3), 7-26. doi:10.5937/industrija43-7648

Birke, D., \& Swann, P. (2006). Network Effects and the Choice of Mobile Phone Operator. Journal of Evolutionary Economics, 16(1-2), 65-84. doi:10.1007/s00191-005-0001-5

Calzada, J., \& Valletti, T.M. (2008). Network Competition and Entry

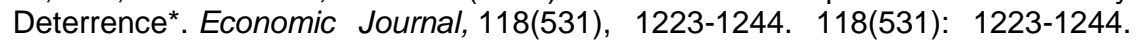
doi:10.1111/j.1468-0297.2008.02167.x

de Bijl, P.W.J., \& Peitz, M. (2004). Dynamic Regulation and Entry in Telecommunications Market: A Policy Framework.Information Economics and Policy, 16(3), 411-437. doi:10.1016/j.infoecopol.2004.01.008

Dessein, W. (2004). Network Competition with Heterogeneous Customers and Calling Patterns. Information Economics and Policy, 16(3), 323-345. doi:10.1016/j.infoecopol.2004.01.004

Doganoglu, T., \& Grzybowski, L. (2007). Estimating Network Effects in Mobile Telephony in Germany. Information Economics and Policy, 19(1), 65-79. doi:10.1016/j.infoecopol.2006.11.001

Gabrielsen, T., \& Vagastad, S. (2008). Why is On-net Traffic Cheaper than Off-net Traffic?, Access Markup as a Collusive Device. European Economic Review, 52(1), 99-115. doi:10.1016/j.euroecorev.2007.02.002

Grajek, M. (2010). Estimating Network Effects and Compatibility: Evidence from Polish Mobile Market. Information Economics and Policy, 22, 130-143. doi:10.1016/j.infoecopol.2009.07.002

Grzybowski, L. \& Pereira, P. (2011). Subscription Choices and Switching Costs in Mobile Telephony, Review of Industrial Organization, 38(1), 23-42. doi: 10.1007/s11151-011-9275-y

Grzybowski, L. \& Liang, J. (2015). Estimating Demand for Fixed-mobile bundles and Switching Costs between Tariffs. Information Economics and Policy, 33, 1-10. doi:10.1016/j.infoecopol.2015.08.002

Hahn, J. (2003). Nonlinear Pricing of Telecommunications with Call and Network Externalities. International Journal of Industrial Organization, 21(7), 949-967. doi:10.1016/S0167-7187(03)00003-1

Hoering, S. (2008). On-net and off-net Pricing on Asymmetric Telecommunications Networks. Information Economics and Policy, 19(2), 171-188. doi:10.1016/j.infoecopol.2007.01.004

Jeon, D., Laffont, J., \& Tirole, J. (2004). On the "Receiver-Pays" Principle. RAND Journal of Economics, 35(1), 35(1): 85. doi:10.2307/1593731

Klemperer, P. (1995). Competition when Consumers Have Switching Costs: An Overview with Applications to Industrial Organization, Macroeconomics and International Trade. Review of Economic Studies, 62(4), 515-539. Retrieved from Business Source Premier, EBSCOhost.

Koski, H., \& Kretschmer, T. (2005). Entry, Standards and Competition: Firm Strategies and the Diffusion of Mobile Telephony. Review of Industrial Organization, 26(1), 89-113. 26(1): 89-113. doi:10.1007/s11151-004-4085-0

Laffont, J., \& Tirole, J. (1994). Access Pricing and Competition. European Economic Review, 38(9), 1673-1710. doi:10.1016/0014-2921(94)90046-9 
Trifunović D., Mitrović Đ.: Network Externalities in Telecommunication Industry: An...

Laffont, J., Rey, P., \& Tirole, J. (1998). Network Competition: I. Overview and Nondiscriminatory Pricing. RAND Journal of Economics, 29(1), 29(1): 1. doi:10.2307/2555814

Laffont, J., Rey, P., \& Tirole, J. (1998). Network Competition: II. Price Discrimination. RAND Journal of Economics, 29(1), 29(1): 38. doi:10.2307/2555815

López, A-L. (2011). Mobile Termination Rates and Receiver Pays Regime. Information Economics and Policy, 23, 171-181. doi:10.1016/j.infoecopol.2011.02.001

Miljković, M., Tanasković, S. \& Filipović, S. (2013). Market Concentration in the Banking Sector: Evidence from Serbia. Industrija, 41(2), 7-26. doi:10.5937/industrija41-4064

Peitz, M. (2005). Asymmetric Access Price Regulation in Telecommunications Markets. European Economic Review, 49(2), 341-358. doi:10.1016/S00142921(03)00046-1

Peitz, M., Valletti, T., \& Wright, J. (2004). Competition in Telecommunications: An Introduction. Information Economics and Policy, 16(3), 315-321. doi:10.1016/S0014-2921(03)00046-1

Ristić, B., \& Trifunović, D. (2014). Horizontal Merger and Weak and Strong Competition Commissions. Economic Annals,59(202), 69-106. doi:10.2298/EKA1402069R

Rohlfs, J. (1974). A Theory of Interdependent Demand for a Communications Service. Bell Journal of Economics and Management Science, 5(1), 5(1): 16. doi: $10.2307 / 3003090$

Shi, M., Chiang, J., \& Rhee, B. (2006). Price Competition with Reduced Switching Costs: The Case of "Wireless Number Portability" in the Cellular Phone Industry. Management Science, 52(1), 27-38. Retrieved from Business Source Premier, EBSCOhost.

Trifunović, D. (2011). Single Object Auctions with Interdependent Values. Economic Annals, 56(188), 125-170. doi:10.2298/EKA1188125T

Trifunović, D., \& Ristić, B. (2013). Multi-unit Auctions in the Procurement of Electricity. Economic Annals, 58(197), 47-78. doi:10.2298/EKA1397047T 